\title{
4 The advantages of political affiliation: dependent and independent small-island profiles
}

\author{
Jerome L. McElroy and Kara B. Pearce
}

\section{INTRODUCTION}

It appears that the independence candle for islands has been snuffed, at least for the moment. The current status is regarded as the best of both worlds. Island jurisdictions wield many of the benefits associated with political sovereignty while they are delegating responsibilities to, and enjoying the security and reaping the material benefits of remaining in association with, a larger, and typically richer, patron (Baldacchino, 2004).

The recent refusal by residents of Tokelau in a February 2006 referendum to opt for full independence from New Zealand and decision to retain their colonial links is no surprise to island scholars (Taitt, 2006). Conservative legislative caution for small sub-national island jurisdictions (SNIJs) and their consistent adherence to the status quo have been hallmarks of the vestiges of empire, particularly in small islands scattered across the globe (Baldacchino, 2006a). The Tokelauan decision to hew to traditional arrangements appears doubly reasonable given the steadily mounting volume of research emphasizing the substantial and enduring socioeconomic and jurisdictional benefits associated with affiliation. The intersection of this research is surfacing from three distinct but tangential niche literatures of the small-island genre: in economic development, political economy and tourism.

Perhaps taking their clues from the natural scientists, early development researchers sought to carve out a special island demography and economy. In the first case Dommen (1980) and others argued for a special island demography based on the propensity of working-age cohorts to migrate for livelihood purposes and a resulting early demographic transition. In the second case the pioneering work of Seers (1964) and Demas (1965) - based principally on the Caribbean with its emphases on small market size, capital goods constraints and export propulsion was followed by the MIRAB (MIgration - Remittances - Aid Bureaucracy) model of Bertram and Watters (1985), drawn mainly from Pacific experience. This construct assumed embedded emigration mobility and posited that small islands subsist primarily on migrant remittances, foreign aid and public employment (bureaucracy). It has become the dominant paradigm in the development literature and, according to Bertram's recent (2006) assessment based on descriptive statistics and case studies, can be applied in varying degrees to some two dozen island societies.

However, a second strand of writing between the borders of development and political economy is challenging the MIRAB orthodoxy. This stream argues that, far 
from being subsidized rentier outposts, small island economies including SNIJs on average possess a private-sector dynamism in their own right. According to Armstrong and Read (2002; 2000), small countries (mainly islands) out-perform larger states and SNIJs outdo their sovereign neighbours. Although Poirine (1998) suggests this latter result is mainly thanks to high levels of per capita aid, this new wave of research, first articulated by Baldacchino and Milne (2000) from North Atlantic experience, argues that much of the insular advantage derives from three factors: (1) domestic policy, namely the deliberate restructuring of the colonial economy of export staples primarily towards international services (tourism and offshore banking); (2) favourable geography (Armstrong and Read, 2006); and (3) the judicious use of jurisdiction and autonomy to manipulate metropolitan linkage for local benefit (Baldacchino and Milne, 2000). A specific example of this so-called PROFIT model (Baldacchino, 2006b) is the creation of island tax havens to attract offshore finance, insurance and foreign sales corporations (Hampton and Abbott, 1998).

Parallel to these currents, an expanding tourism literature has consistently emphasized the increasing importance of the visitor industry in small islands in general (Apostolopoulos and Gayle, 2002; Briguglio et al., 1996; Beller et al., 1990), and in the Caribbean (McElroy and de Albuquerque, 1998), the Mediterranean (Tsartas, 1992), and the Pacific (Milne, 1992) in particular. Recent studies have indirectly linked insular tourism success with the assumed favourable economic advantages of affiliation. These include ease of trade with and travel from affluent metropolitan visitor origin markets (no passport, same language, currency, customs, etc.), ready access to private investment capital and off-island managerial/marketing expertise, aid-financed transport and communications infrastructure, special tax and duty-free gift/souvenir/liquor concessions and the like (McElroy, 2003). In fact, Bertram (2004) contends that the superior performance of SNIJs is directly linked to their degree of centre-periphery trade, aid and investment dependence and the affluence achieved by their respective metropolitan patrons. Finally, McElroy (2006) argues primarily from Caribbean and Northern Pacific experiences that the unique synergy between political dependence and insular tourism success is suggestive of a distinct development case, embracing small-island tourism-driven economies (SITES).

\section{SCOPE AND METHOD}

Most studies examining the advantages of affiliation have concentrated mainly on a small range of economic indicators (per capita income, growth, aid, structure). One exception is McElroy and Sanborn's (2005) construction of comprehensive socioeconomic and demographic profiles contrasting 16 SNIJs and 19 independent islands in the Caribbean and Pacific. Among other things, this study concluded that the former were significantly more affluent and tourist-driven, with higher life expectancy and literacy rates, and lower fertility, and natal and infant mortality than their sovereign neighbours. In short, the SNIJs had more successfully restructured their colonial economies towards international services and achieved greater progress along the demographic transition. The present article expands this effort to determine whether the same advantages obtain across a considerably larger global sample of small islands. 
To construct distinct socioeconomic and demographic profiles, 25 variables were selected. Eight were employed to measure macroeconomic performance and structure: per capita GDP, a standard of living proxy; per capita electricity consumption; the labour force participation rate (LFPR) and unemployment rates; share of GDP in agriculture, and in industry and services; and land area as a proxy for general resource availability. To gauge tourism's importance two aggregate measures were used: per resident visitor expenditure and the gross ratio of visitors to the resident population. Since the average length of visitor stay for overnight tourists is roughly seven days, day-trippers (mainly cruise ship passengers) were weighted oneseventh, i.e. by a factor of 0.14 . To measure social and health differences, four standard indicators were used: life expectancy, adult literacy, infant mortality and the number of land phone lines per 1000 population. Finally, 11 variables were employed to monitor demographic differences: population size, growth and density, median age, and the distribution into young $(0-14 \mathrm{yrs})$, working-age $(15-64 \mathrm{yrs})$ and old $(65+$ yrs $)$ cohorts. In addition, birth, death, migration and fertility rates were used.

The two tourism indicators were developed from the Compendium of Tourism Statistics (WTO, 2005). All other variables were taken from the World Factbook (CIA, 2005). To construct distinct statistical profiles of the SNIJs and independent islands, average values across the 25 variables were calculated for each respective group, and statistical differences were determined using a two-sample means test. To operationalize the test, 55 small islands were selected of less than one million in population, with two exceptions - Mauritius (1.2 million) and Trinidad and Tobago (1.1 million) - for which nearly complete data were available. Because of the heavy data requirements necessary to construct the comprehensive profiles, as well as the need to use comparable indicators from a unitary standard source(s), many (especially small) SNIJs were excluded from the analysis. The resulting sample comprised 25 non-sovereign and 30 independent islands spanning all major oceanic regions. They comprised 19 in the Caribbean, 17 in the Pacific, nine in the Atlantic, seven in the Indian Ocean, two in the Mediterranean (Cyprus and Malta) and Bahrain in the Persian Gulf. Given previous research, it was hypothesized that the dependent islands would exhibit higher levels of socioeconomic performance, tourism development and demographic maturity than their sovereign counterparts.

\section{RESULTS}

The Appendix contains the basic data for the 55-island sample (see Appendix 4.1), while Table 4.1 displays average values of the 25 indicators for the two island groupings classified by political status. P-values are provided to assess statistical significance based on the two-sample means test. In general results conform to expectations. In all cases the average values of the SNIJ profile contrast with those of the independent profile in the hypothesized directions. Basically the outcomes of this global comparison confirm results from the smaller-scale, Caribbean-Pacific pilot study (McElroy and Sanborn, 2005). There are empirically verifiable and distinct socioeconomic and demographic differences among small islands dichotomously stratified according to political status.

According to the data, the SNIJs clearly differ in size, economic behaviour and structure from the sovereign countries. To illustrate, with respect to basic resource 
Table 4.1 Dependent versus independent island profiles

\begin{tabular}{lccc}
\hline Variable & Dependents & Independents & P-Values (1) \\
\hline Area $\left(\mathrm{Km}^{2}\right)$ & 1390 & 3680 & 0.133 \\
Population & 142 & 318 & $0.016^{*}$ \\
GDP per capita (US\$) & 17416 & 8463 & $0.014^{*}$ \\
Electricity/pop (2) & 4188 & 1994 & $0.010^{*}$ \\
Labour force/pop & 44.0 & 40.7 & 0.281 \\
Unemployment rate & 11.6 & 15.0 & 0.415 \\
$\%$ Agriculture/GDP & 7.0 & 14.5 & $0.014^{*}$ \\
$\%$ Industry/GDP & 18.4 & 20.6 & $0.412^{*}$ \\
\% Services/GDP & 77.6 & 64.9 & $0.000^{*}$ \\
Visitor spending/pop (\$US) & 6044 & 1207 & $0.001^{*}$ \\
Visitors/pop & 4.6 & 1.5 & $0.008^{*}$ \\
Life expectancy & 76.8 & 70.0 & $0.000^{*}$ \\
Literacy rate & 94.9 & 90.5 & 0.058 \\
Infant mortality rate & 11.5 & 24.0 & $0.003^{*}$ \\
Population density & 363 & 307 & 0.651 \\
Phones/pop & 473 & 248 & $0.002^{*}$ \\
$\%$ 0-14 yrs & 24.3 & 30.8 & $0.002^{*}$ \\
$\%$ 15-64 yrs & 66.8 & 63.2 & $0.019^{*}$ \\
\% 65+ yrs & 9.0 & 5.7 & $0.003^{*}$ \\
Median age & 32.2 & 25.5 & $0.000^{*}$ \\
Crude birth rate & 16.3 & 21.7 & $0.009^{*}$ \\
Crude death rate & 6.3 & 6.8 & $0.347^{*}$ \\
Total fertility rate & 2.2 & 2.8 & $0.018^{*}$ \\
Population growth & 1.2 & 1.1 & 0.683 \\
Net migration rate & 1.9 & -3.8 & $0.003^{*}$ \\
\hline
\end{tabular}

Sources: See Appendix.

Notes

1 Asterisk denotes statistical significance at the 0.05 level or better.

2 Iceland was excluded from this analysis since it is a major producer of electricity and the indicator would measure more about larger-scale industrial production than general economic activity.

availability, the independents are between two and three times larger on average in both area and population. This subgroup contains the largest islands in the total sample in area (Iceland, Solomons) as well as in population (Mauritius, Trinidad, Fiji, Cyprus). Only the latter characteristic, however, is statistically significant. On the other hand, the SNIJs' superior economic performance tends to compensate for their relative resource scarcity. Most importantly, they average twice the level of per capita GDP - $\$ 17,416$ compared with $\$ 8463$ - the most common indicator for measuring standard of living differences. Likewise, in comparison with the sovereign countries, SNIJs average over twice the annual per capita electricity consumption - 4188 to $1994 \mathrm{KWh}$ - another standard proxy indicator for living levels. In similar fashion the means of the two labour utilization variables are in the hypothesized directions. For example, LFPR - the labour force divided by the population - is higher for the SNIJs, at $44 \%$ versus $41 \%$, indicating a more economically active citizenry. In addition, their unemployment rate is lower, $11.6 \%$ versus $16 \%$. In both cases, however, the differences are not statistically significant.

According to Table 4.1, there are also sharp differences in economic structure between the two groups. The economies of the SNIJs are considerably less reliant on 
primary production and more oriented towards services. In the first case primary activity (mainly agriculture) absorbs only $7 \%$ of GDP, whereas it averages over $17 \%$ in the independents. This is not surprising since the independents include a number of low-income, remote agricultural/subsistence economies: Comoros, Kiribati, Micronesia, Solomons and Vanuatu. In the second case service activity predominates in the SNIJs, nearly $78 \%$ compared with $65 \%$. These statistically different structural contours in combination with their associated differences in levels of affluence indicate that the SNIJs have more successfully diversified away from income-inelastic colonial staples (sugar, copra, etc.) towards income-elastic services like tourism and offshore finance. This is evident in the five-fold discrepancy in visitor spending per resident in favour of the SNIJs, $\$ 6044$ versus $\$ 1207$, and in the nearly three-fold advantage they exhibit on average against the sovereign islands in the ratio of gross visitors to resident population (4.6 to 1.5$)$. It is expected that the SNIJs are more tourism-intensive, since this sub-sample contains many of the most popular destinations in the Caribbean, the most tourism-penetrated region in the world (McElroy, 2004): Aruba, British and American Virgin Islands, Caymans, and Turks and Caicos. It also contains the two Northern Pacific US SNIJs of Guam and Northern Marianas, which are highly developed resort areas catering mainly to the Asian market. In addition, this SNIJ group also includes many successful offshore tax and finance havens in the Caribbean (British Virgins and Caymans), Atlantic (Bermuda) and North Atlantic (Isle of Man, Guernsey and Jersey).

Social patterns also differ between the two profiles. This is particularly true in health standards. For example, life expectancy averages almost seven years higher for the SNIJs (76.8 v. $70 \mathrm{yrs}$ ), and their infant mortality averages half the rate of their sovereign neighbours, at 12 versus 24 deaths per 1000 live births. Among other things, these more favourable health indices for the SNIJs may in part reflect better access to medical care given their smaller geographic size and relatively higher average population density $\left(363 \mathrm{v} .307 / \mathrm{km}^{2}\right)$. In addition, the SNIJs' higher average adult literacy rate of $95 \%$ exceeds the independents' rate by nearly 5 points $(90.5 \%)$ although the difference is statistically significant only at the $6 \%$ level. This advantage may be partly a result, or a reflection, of differential information and media access. As a proxy for these influences, telephone usage (excluding cellular) per 1000 population is significantly higher among the SNIJs (473) than among the independents (248). However, it is perhaps their relative affluence and closer adherence to and institutional support for metropolitan standards and regulations that explain most of the their superior health and educational performance.

As hypothesized, the two demographic profiles diverge markedly across almost every indicator. While the sovereign islands exhibit a decidedly young population structure with over $30 \%$ younger than 15 years old, the more affluent SNIJs, with their higher labour force participation rates and more dynamic economies, boast an older age profile with a considerably higher median age (32.2 to $25.5 \mathrm{yrs}$ ). This is the result of their larger share of retirees $(65+\mathrm{yrs}), 9.0 \%$ to $5.7 \%$, and working-age cohorts $(15-64 \mathrm{yrs}), 66.8 \%$ to $63.2 \%$, swollen by a heavy influx of migrants to service the labour-intensive requirements of expanding tourism, related construction and offshore activities. The different net migration patterns are also clearly evident in Table 4.1. For example, SNIJs average net immigration of roughly two persons per 1000 population in contrast to average net emigration from the independents of nearly four per 1000 . Some rather extreme examples highlight this contrasting 
pattern. Net emigration from two stagnant independents, Micronesia and Grenada, was 21 per 1000 and 13 per 1000 , respectively, indicating a population loss of between $1 \%$ and $2 \%$ per annum. Just the reverse case is the net immigration experience of two of the fastest-growing Caribbean tourist SNIJs, the Cayman Islands and the Turks and Caicos Islands (18 per 1000 and 11 per 1000, respectively). Aside from the wide per capita GDP differences noted earlier, perhaps no other variable better captures the structural divide between the profiles than these differential migration experiences, which discriminate between the dynamic, labour-importing SNIJs and their slower-growing, labour-exporting sovereign counterparts.

Finally, the dependencies also demonstrate greater progress through the demographic transition from higher to lower birth and death rates - a common index of development. They average considerably lower crude birth rates than the independents, 16 v. 22 births per 1000 population, and slightly lower crude death rates than the independents, six v. roughly seven per 1000 population. Similarly their total fertility rates average fewer children $(2.2 \mathrm{v}$. 2.8) per woman of child-bearing age. As a result of these patterns, the SNIJs' average rate of natural increase (birth minus death rates) is noticeably lower, as expected $(1 \%$ v. $1.5 \%)$. On the other hand, average annual population growth is slightly higher in the SNIJs $(1.2 \%$ to $1.1 \%)$ because of their heavy net immigration. In comparison with the independent islands these demographic contours are partly a reflection of the SNIJs' relative affluence, older age structure and better health standards. In general these small non-sovereign islands exhibit higher levels of demographic maturity and modernization.

\section{DISCUSSION}

This study has argued that the expanding research on small island economies is emerging on three legs: the dominant MIRAB model with roots in the Pacific, the socalled PROFIT or jurisdictional model first developed in the North Atlantic, and the tourism-driven SITES model originally conceived in the Caribbean. Where all three constructs intersect is their common emphasis, in varying degrees, on the flexible and enduring advantages of political affiliation. The present analysis has attempted to strengthen this common thread by establishing in comprehensive detail the superior socioeconomic and demographic performance of SNIJs over their independent counterparts. On the basis of this body of evidence, it further argues, albeit indirectly, that this favourable performance derives partly from metropolitan political and economic ties and partly from the SNIJs' creative use of jurisdiction. According to Baldacchino (2004, p. 9), these sub-national island jurisdictions should be seen "as political innovators, testing out the limits of possibility which insularity, small size, location, and a measure of administrative autonomy may offer". In brief, conscious of the substantial benefits and policy autonomy associated with affiliation, nonsovereign islanders like the Tokelauans have repeatedly opted over the past two decades to retain the status quo (Hintjens, 1997; McElroy and de Albuquerque, 1996).

In this study a global sample of 55 small islands with roughly less than a million in population was broken down into two groups comprising 25 dependencies and 30 sovereign islands. Profiles were constructed using two-sample means analysis across 25 variables. Results clearly and comprehensively demonstrated the favourable 
performance of the SNIJs over the independents. Though smaller in size, the former economies were considerably more affluent, and were diversified towards the most sustained growth engine in the world economy, international tourism, and to a lesser extent offshore finance. In addition, the SNIJs enjoyed higher life expectancy, adult literacy and communication access (phone lines per 1000 population) and lower infant mortality, natal and fertility rates than their sovereign neighbours.

What about the future? Whereas the tourism viability of these service-oriented SNIJs is anchored to the sustained growth of the global visitor industry, the situation is less assured for offshore finance. Growing concerns about overseas money laundering and tax evasion among the OECD countries in 1997 prompted their Financial Action Task Force (FATF) to publish a list of some 15 so-called 'noncooperative' countries and territories in 2000. The latter included SNIJs in the Caribbean (Cayman Islands) and the Pacific (Cook Islands, Marshall Islands). Their various weaknesses included excessive secrecy, regulatory loopholes, and inadequate reporting and international cooperation. Although many islands have since made significant institutional and regulatory reforms, and some have achieved de-listing, the damage has been done and a stigma is attached to offshore activity. Because of intensifying global competition, increased international scrutiny and the high costburden of setting up the required best-practice financial framework to maintain compliance, Suss et al. (2005, p. 602) caution insular policy makers "to evaluate carefully a decision to establish, or to expand any existing, offshore sector". In other words, the future expansion of offshore activity in SNIJs is projected to be less buoyant than in the past.

\section{CONCLUSION}

In summary, this study has shown that the SNIJs are more economically developed, socially advanced and demographically progressive than the independent island countries. This differential performance is perhaps best encapsulated in the disparate migration experiences characteristic of the two distinct profiles. On the one hand, the average independent island is typically an emigrant society experiencing slow growth, labour surplus and chronic emigration. On the other hand, the average SNIJ is typically an immigrant society that had passed through the migration transition from labour exporter to labour importer largely thanks to the labour-intensive imperatives of a dynamic international service economy. Further research will test whether these differences obtain in the longer run. In the meantime, the research provides a detailed look at the contours associated with the more successful tourist-driven SNIJs, i.e. the so-called SITES (McElroy, 2006), favoured by geography, close metropolitan ties, and an endogenous policy of export service promotion. It may also provide a springboard for future case studies more directly linking the SNIJs' socioeconomic and demographic advantages to the islands' various exercises of autonomy, and specific status and jurisdictional arrangements.

\section{References}

Apostolopoulos, Y. and Gayle, D. J. (Eds) (2002) Island Tourism and Sustainable Development: Caribbean, Pacific and Mediterranean Experiences (Westport, CT: Praeger). 
Armstrong, H. and Read, R. (2000) Comparing the economic performance of dependent territories and sovereign micro-states, Economic Development and Cultural Change, 48, pp. 285-306.

Armstrong, H. and Read, R. (2002) The phantom of liberty? Economic growth and the vulnerability of small states, Journal of International Development, 14(3), pp. 435-458.

Armstrong, H. and Read, R. (2006) Geographical 'handicaps' and small states: some implications for the Pacific from a global perspective, Asia Pacific Viewpoint, 47(1), pp. 79 92.

Baldacchino, G. (2004) Autonomous but not sovereign? A review of island sub-nationalism, Canadian Review of Studies in Nationalism, 31, pp. 1-13.

Baldacchino, G. (2006a) Innovative development strategies from non-sovereign island jurisdictions? A global review of economic policy and governance practices, World Development, 34(5), pp. 852-867.

Baldacchino, G. (2006b) Managing the hinterland beyond: two ideal-type strategies of externality management for small island territories, Asia Pacific Viewpoint, 47(1), pp. 45-60.

Baldacchino, G. and Milne, D. (Eds) (2000) Lessons from the Political Economy of Small Islands: The Resourcefulness of Jurisdiction (Basingstoke: Macmillan).

Beller, W., d'Ayala, P. and Hein, P. (Eds) (1990) Sustainable Development and Environmental Management of Small Islands (Paris: UNESCO).

Bertram, G. (2004) On the convergence of small island economies with their metropolitan patrons, World Development, 32(2), pp. 343-364.

Bertram, G. (2006) Introduction: The MIRAB model in the twenty-first century, Asia Pacific Viewpoint, 47(1), pp. 1-13.

Bertram, G. and Watters, R. F. (1985) The MIRAB economy in South Pacific microstates, Pacific Viewpoint, 26(3), pp. 497-519.

Briguglio, L., Archer, B., Jafari, J. and Wall, G. (Eds) (1996) Sustainable Tourism in Islands and Small States, Vol. 1, Issues and Policies (London: Pinter).

Central Intelligence Agency (2005) The World Factbook 2005 (Washington, DC: CIA), at http://www.odci.gov/cia/publications/Factbook/index.html, accessed 15 February 2006.

Demas, W. G. (1965) The Economics of Development in Small Countries with Special Reference to the Caribbean (Montreal: McGill University Press).

Dommen, E. (1980) Some distinguishing characteristics of island states, World Development, 8(12), pp. 931-943.

Hampton, M. P. and Abbott, J. P. (Eds) (1998) Offshore Finance Centres and Tax Havens: The Rise of Global Capital (Basingstoke: Macmillan).

Hintjens, H. M. (1997) Governance options in Europe's Caribbean dependencies, The Round Table, 344, pp. 535-547.

McElroy, J. L. (2003) Tourism development in small islands across the world, Geografiska Annaler, 85 B(4), pp. 231-242.

McElroy, J. L. (2004) Global perspectives on Caribbean tourism, in D. T. Duval (Ed.), Tourism in the Caribbean: Trends, Development, Prospects, pp. 39-56 (London: Routledge).

McElroy, J. L. (2006) Small island tourist economies across the life cycle, Asia Pacific Viewpoint, 47(1), pp. 61-77.

McElroy, J. L. and De Albuquerque, K. (1996) The social and economic propensity for polical dependence in the insular Caribbean, Social and Economic Studies, 44(1), pp. 167-193.

McElroy, J. L. and De Albuquerque, K. (1998) Tourism penetration index in small Caribbean islands, Annals of Tourism Research, 25(1), pp. 145-168.

McElroy, J. L. and Sanborn, K. (2005) The propensity for dependence in small Caribbean and Pacific islands, Bank of Valletta Review, 31(spring), pp. 1-16.

Milne, S. (1992) Tourism and development in South Pacific microstates, Annals of Tourism Research, 19, pp. 191-212. 
Poirine, B. (1998) Should we love or hate MIRAB?, The Contemporary Pacific, 10(1), pp. 65105.

Seers, D. (1964) The mechanisms of an open petroleum economy, Social and Economic Studies, 13(2), pp. 233-242.

Suss, E., Williams, O. and Mendis, C. (2005) Caribbean offshore financial centers: past, present and possibilities for the future, in D. Pantin (Ed.), The Caribbean Economy: A Reader. pp. 590-616 (Kingston: Ian Randle).

Taitt, M. (2006) Tokelauans say no to self-determination, Fairtax New Zealand Ltd, 17 February, at http://www.co.n2/stuff/0,2106,3574530a12,00.html, accessed 17 February 2006.

Tsartas, P. (1992) Socioeconomic impacts of tourism on two Greek isles, Annals of Tourism Research, 19, pp. 191-212.

World Tourism Organization (2005) Compendium of Tourism Statistics 2005 (Madrid: WTO). 


\begin{tabular}{|c|c|c|c|c|c|c|c|c|c|c|c|c|c|c|c|c|c|c|c|c|c|c|c|c|c|c|}
\hline \multirow[b]{2}{*}{ Island } & \multirow{2}{*}{$\begin{array}{l}\text { Area } \\
\left(\mathrm{km}^{2}\right)\end{array}$} & \multirow{2}{*}{$\begin{array}{l}\text { Pop. } \\
\text { (OO0) }\end{array}$} & \multicolumn{3}{|c|}{ Age distribution $\%$} & \multirow{2}{*}{$\begin{array}{c}\text { Median } \\
\text { Age }\end{array}$} & \multirow{2}{*}{$\begin{array}{c}\text { Pop. } \\
\text { Growth }\end{array}$} & \multirow{2}{*}{$\begin{array}{c}\text { Pop. } \\
\text { Density }\end{array}$} & \multirow[b]{2}{*}{$C B R$} & \multirow[b]{2}{*}{$C D R$} & \multirow[b]{2}{*}{$N M R$} & \multirow[b]{2}{*}{$I M R$} & \multirow[b]{2}{*}{ TFR } & \multirow[b]{2}{*}{$L E$} & \multirow{2}{*}{$\begin{array}{c}L I T \\
\%\end{array}$} & \multirow{2}{*}{$\begin{array}{c}\text { GDP/ } \\
\text { Pop. } \\
(U . S . S)\end{array}$} & & $\%$ & & & & & & & & \\
\hline & & & $(0-14)$ & $(15-64)$ & $(65+1)$ & & & & & & & & & & & & Agr. & Ind. & Ser. & LFPR & UN 1 & Millions & $(000)$ & (US S) & & (4) \\
\hline Amer. Samoa & 199 & 57.9 & 36 & 61 & 3 & 22.8 & -0.11 & 291 & 23.1 & 3.3 & -20.90 & 9.3 & 3.3 & 75.8 & 97.0 & 8000 & - & - & - & 24 & 6.0 & 120.9 & 259.1 & 450 & 0.7 & 0 \\
\hline Anguilla & 102 & 13.3 & 23 & 70 & 7 & 30.8 & 1.77 & 131 & 14.3 & 5.4 & 8.80 & 21.0 & 1.7 & 77.1 & 95.0 & 7500 & 4.0 & 18.0 & 78.0 & 45 & 8.0 & 42.6 & 466.2 & 4662 & 4.1 & 0 \\
\hline Aruba & 193 & 71.6 & 20 & 68 & 12 & 38.0 & 0.47 & 371 & 11.3 & 6.6 & 0.00 & 5.9 & 1.8 & 79.1 & 97.0 & 28000 & 1.0 & 15.0 & 84.0 & 58 & 0.6 & 716.1 & 518.2 & 11900 & 10.0 & 0 \\
\hline Bermuda & 50 & 65.4 & 19 & 69 & 12 & 39.8 & 0.64 & 1308 & 11.6 & 7.6 & 2.50 & 8.5 & 1.9 & 77.8 & 98.0 & 36000 & 1.0 & 10.0 & 89.0 & 57 & 5.0 & 580.3 & 856.3 & 5658 & 4.4 & 0 \\
\hline British V.I. & 150 & 22.6 & 21 & 74 & 5 & 31.0 & 2.06 & 151 & 15.0 & 4.4 & 10.00 & 18.1 & 1.7 & 76.5 & 97.8 & 38500 & 1.8 & 6.2 & 92.0 & 57 & 3.0 & 32.1 & 517.7 & 15797 & 14.1 & 0 \\
\hline Caymans & 260 & 44.3 & 21 & 71 & 8 & 36.8 & 2.64 & 170 & 12.9 & 4.8 & 18.25 & 8.2 & 1.9 & 80.0 & 98.0 & 32300 & 1.4 & 3.2 & 95.4 & 45 & 4.1 & 411.0 & 857.8 & 11693 & 12.4 & 0 \\
\hline Cook Islands & 240 & 21.4 & - & - & - & - & - & 89 & - & - & - & - & - & - & 95.0 & 5000 & 17.0 & 7.8 & 75.2 & 36 & 13.0 & 26.0 & 289.7 & 2337 & 3.6 & 0 \\
\hline Faeroe Islands & 1399 & 46.9 & 21 & 65 & 14 & 35.1 & 0.62 & 5 & 14.0 & 8.7 & 0.94 & 6.2 & 2.2 & 79.0 & - & 22000 & 27.0 & 11.0 & 62.0 & 52 & 1.0 & 242.0 & 490.4 & - & - & 0 \\
\hline Guadeloupe & 1706 & 448.7 & 24 & 67 & 9 & 31.8 & 0.92 & 263 & 15.4 & 6.1 & -0.15 & 8.6 & 1.9 & 77.9 & 90.0 & 7900 & 15.0 & 17.0 & 68.0 & 28 & 27.8 & 1100.0 & 468.0 & 892 & 1.0 & 0 \\
\hline Guam & 541 & 168.6 & 29 & 64 & 7 & 28.4 & 1.46 & 312 & $\begin{array}{l}13.4 \\
19.0\end{array}$ & $\begin{array}{l}0.1 \\
4.4\end{array}$ & 0.00 & $\begin{array}{l}.00 \\
6.9\end{array}$ & 2.6 & 78.4 & 99.0 & 21000 & 7.0 & 15.0 & 78.0 & 36 & 15.0 & 781.3 & 498.8 & 12041 & 5.4 & 0 \\
\hline Guernsey & 78 & 65.2 & 15 & 67 & 18 & 41.0 & 0.29 & 836 & 9.0 & 9.9 & 3.83 & 4.7 & 1.4 & 80.0 & - & 40000 & 3.0 & 10.0 & 87.0 & 50 & 0.5 & - & 843.6 & - & - & 0 \\
\hline Isle of Man & 572 & 75.0 & 17 & 66 & 17 & 39.5 & 0.52 & 131 & 11.2 & 11.3 & 5.33 & 5.9 & 1.7 & 78.3 & - & 28000 & 1.0 & 13.0 & 86.0 & 53 & 0.6 & - & 680.0 & - & - & 0 \\
\hline Jersey & 116 & 90.8 & 18 & 67 & 16 & 40.9 & 0.32 & 783 & 9.7 & 9.2 & 2.80 & 5.2 & 1.6 & 79.2 & - & 40000 & 5.0 & 2.0 & 93.0 & 58 & 0.9 & 630.1 & 813.9 & - & - & 0 \\
\hline Marrinique & 1060 & 439.9 & 22 & 67 & 11 & 33.6 & 0.76 & 2430 & 14.1 & 6.4 & -0.04 & 7.1 & 1.8 & 79.0 & 97.7 & 14400 & 6.0 & 11.0 & 83.0 & 38 & 27.2 & 1100.0 & 391.0 & 561 & 1.1 & 0 \\
\hline Mayotte & 374 & 193.6 & 46 & 52 & 2 & 16.9 & 3.93 & 518 & 41.6 & 7.9 & 5.62 & 62.4 & 5.9 & 61.4 & $68(1)$ & 2600 & - & - & - & $30(1)$ & 38.0 & - & 51.7 & - & - & 0 \\
\hline Montserrat & 100 & 9.3 & 23 & 66 & 11 & 28.6 & 1.04 & 93 & 17.6 & 7.2 & 0.00 & 7.4 & 1.8 & 78.7 & 97.0 & 3400 & 5.4 & 13.6 & 81.0 & 48 & 6.0 & 1.9 & - & 1075 & 1.0 & 0 \\
\hline N. Caledonia & 18575 & 216.5 & 29 & 65 & 6 & 27.5 & 1.30 & 12 & 18.5 & 5.7 & 0.00 & 7.7 & 2.3 & 74.0 & 91.0 & 15000 & 5.0 & 30.0 & 65.0 & 37 & 19.0 & 1500.0 & 240.2 & 531 & 0.5 & 0 \\
\hline No. Marianas & 477 & 80.4 & 20 & 79 & 2 & 29.3 & 2.61 & 169 & 19.5 & 2.3 & 8.92 & 7.1 & 1.3 & 75.9 & 97.0 & 12500 & 5.0 & 20.0 & $75(1)$ & 53 & 7.8 & - & 261.2 & 9760 & 5.6 & 0 \\
\hline Polynesia & 3660 & 270.5 & 27 & 67 & 6 & 27.5 & 1.52 & 74 & 16.9 & 4.6 & 2.89 & 8.4 & 2.0 & 75.9 & 98.0 & 17500 & 6.0 & 28.0 & 76,0 & 26 & 11.8 & 459.2 & 194.1 & 1479 & 0.8 & 0 \\
\hline Reunion & 2500 & 776.9 & 30 & 64 & 6 & 26.7 & 1.38 & 311 & 19.3 & 5.5 & 0.00 & 7.8 & 2.5 & 73.9 & 90.0 & 6200 & 8.0 & 19.0 & 73.0 & 40 & 36.0 & 1100.0 & 386.2 & 400 & 0.6 & 0 \\
\hline $\begin{array}{l}\text { Netherland } \\
\text { Antilles }\end{array}$ & 960 & 219.9 & 24 & 67 & 9 & 32.5 & 0.82 & 229 & 15.0 & 6.4 & -0.40 & 10.0 & 2.0 & 75.8 & 96.7 & 11400 & 1.0 & 15.0 & 84.0 & 40 & 15.6 & 945.8 & 368.3 & $3237(3)$ & $2.9(3)$ & 0 \\
\hline St Helena & 410 & 7.5 & 19 & 71 & 10 & 35.4 & 0.59 & 18 & 12.3 & 6.4 & 0.00 & 19.0 & 1.5 & 77.8 & 97.0 & 2500 & 5.0 & 40.0 & $55(1)$ & 47 & 14.0 & 4.7 & 293.3 & - & - & 0 \\
\hline $\begin{array}{l}\text { St Pierre/ } \\
\text { Miquelon }\end{array}$ & 242 & 7.0 & 24 & 65 & 11 & 3 & 0.21 & 29 & 13.8 & 6.7 & -4.99 & 7.5 & 2.0 & 78.5 & 99.0 & 7000 & 20.0 & 30.0 & $50(1)$ & 47 & 9.8 & 41.1 & 685.7 & - & - & 0 \\
\hline Turks/Caicos & 430 & 20.5 & 33 & 64 & 4 & 27.4 & 2.90 & 48 & 22.2 & 4.3 & 11.09 & 15.7 & 3.1 & 74.5 & 98.0 & 11500 & 15.0 & 10.0 & $75(1)$ & 50 & 10.0 & 4.7 & 278.0 & 14634 & 8.0 & 0 \\
\hline US Virgins & 349 & 108.7 & 23 & 66 & 11 & 36.5 & -0.07 & 311 & 14.2 & 6.3 & -8.64 & 8.0 & 2.2 & 78.9 & $96(1)$ & 17200 & 1.0 & 19.0 & 80.0 & 45 & 9.3 & 967.3 & 63 & 11693 & 7.3 & 0 \\
\hline Antigua & 440 & 68.7 & 28 & 68 & 4 & 29.7 & 0.57 & 156 & 17.3 & 5.4 & -6.11 & 19.5 & 2.3 & 71.9 & 89.0 & 11000 & 3.9 & 19.2 & 76.8 & 43 & 11.0 & 93.0 & 553.1 & 4204 & 3.9 & 1 \\
\hline Bahrain & 620 & 688.3 & 28 & 69 & 3 & 29.2 & 1.51 & 1110 & 18.1 & 4.1 & 1.04 & 17.3 & 2.6 & 74.2 & 89.0 & 20500 & 0.6 & 42.5 & 56.9 & 55 & 15.0 & 6800.0 & 269.9 & 1431 & 4.7 & 1 \\
\hline Bahamas & 10070 & 301.8 & 28 & 66 & 6 & 27.6 & 0.67 & 30 & 17.9 & 9.0 & -2.18 & 25.2 & 2.2 & 65.5 & 95.6 & 18800 & 3.0 & 7.0 & 90.0 & 52 & 10.2 & 1700.0 & 436.4 & 5948 & 6.4 & 1 \\
\hline Barbados & 430 & 279.2 & 21 & 71 & 9 & 34.2 & 0.33 & 649 & 12.8 & 9.2 & -0.31 & 12.5 & 1.7 & 72.6 & 99.7 & 17300 & 6.0 & 16.0 & 78.0 & 46 & 10.7 & 761.7 & 479.9 & 2747 & 2.2 & 1 \\
\hline Cape Verde & 4030 & 418.2 & 39 & 54 & 7 & 19.4 & 0.67 & 104 & 25.3 & 6.6 & -11.90 & 47.8 & 3.5 & 70.5 & 76.7 & 6200 & 12.0 & 23.0 & 66.0 & 30 & 21.0 & 41.4 & 171.4 & 328 & 0.3 & 1 \\
\hline Comoros & 2170 & 671.2 & 43 & 54 & 3 & 18.6 & 2.91 & 309 & 37.5 & 8.4 & 0.00 & 74.9 & 5.1 & 62.0 & 56.5 & 600 & 40.0 & 4.0 & 56.0 & 22 & 20.0 & 16.7 & 19.7 & 18 & 0.0 & 1 \\
\hline Cyprus & 9240 & 780.1 & 21 & 68 & 11 & 34.7 & 0.54 & 84 & 12.6 & 7.6 & 0.43 & 7.2 & 1.8 & 77.7 & 97.6 & 21600 & 3.8 & 20.0 & 76.2 & 47 & 3.5 & 3500.0 & 547.9 & 2875 & 3.0 & 1 \\
\hline Dominica & 750 & 69.0 & 27 & 65 & 8 & 29.6 & -0.27 & 92 & 15.7 & 6.8 & -11.60 & 14.2 & 2.0 & 74.7 & 94.0 & 5500 & 18.0 & 24.0 & 58.0 & 36 & 23.0 & 65.1 & 343.5 & 739 & 1.4 & 1 \\
\hline Fiji & 18270 & 893.4 & 31 & 65 & 4 & 24.3 & 1.40 & 49 & 22.7 & 5.7 & -3.00 & 12.6 & 2.8 & 69.5 & 93.7 & 6000 & 16.6 & 22.4 & 61.0 & 15 & 7.6 & 721.4 & 114.2 & 601 & 0.8 & 1 \\
\hline Grenada & 340 & 89.5 & 34 & 63 & 3 & & 0.19 & 263 & 22.3 & 7.2 & -13.25 & 14.6 & 2.4 & 64.5 & 98.0 & 5000 & 7.7 & 23.9 & 68 & 47 & 12.5 & 148.6 & 374.3 & 1162 & 1.8 & 1 \\
\hline Icel & 103000 & 296.7 & 22 & 66 & 12 & 34.0 & 0.91 & 3 & 13.7 & 6.7 & 2.06 & 3.3 & 1.9 & 80.1 & 99.9 & 34600 & 12.0 & 22.0 & 66 & 54 & 2.1 & 7800.0 & 642.7 & 1641 & 2.6 & 1 \\
\hline Kiribati & 811 & 103.1 & 39 & 58 & 3 & 20.1 & 2,25 & 127 & 30.9 & 8.4 & 0.00 & 48.5 & 4.2 & 61.7 & $85(1)$ & 800 & 30.0 & 7.0 & 63 & 30 & 2.0 & 11.1 & 43.6 & 40 & 0.1 & 1 \\
\hline Maldives & 300 & 349.1 & 44 & 53 & 3 & 17.7 & 2.82 & 1164 & 35.4 & 7.2 & 0.00 & 56.5 & 5.0 & 64.1 & 97.2 & 3900 & 20.0 & 18.0 & 62.0 & 25 & 5.0 & 125.6 & 82.2 & 1152 & 1.6 & 1 \\
\hline Malta & 320 & 398.5 & 18 & 69 & 14 & 38.4 & 0.42 & 1245 & 10.2 & 8.0 & 2.06 & 3.9 & 1.5 & 78.9 & 92.8 & 18800 & 3.0 & 23.0 & 74.0 & 40 & 7.0 & 1900.0 & 522.7 & 2148 & 3.0 & 1 \\
\hline Marshall is & 181 & 59.1 & 28 & 59 & 3 & 19.9 & 2.27 & 327 & 33.5 & 4.9 & -5.91 & 29.5 & 3.9 & 70.0 & 93.7 & 1600 & 14.0 & 16.0 & 70.0 & 49 & 30.9 & - & 76.1 & 102 & 0.1 & 1 \\
\hline
\end{tabular}


Appendix Table 4.1 (Continued)

\begin{tabular}{|c|c|c|c|c|c|c|c|c|c|c|c|c|c|c|c|c|c|c|c|c|c|c|c|c|c|c|}
\hline \multirow[b]{2}{*}{ Island } & \multirow{2}{*}{$\begin{array}{l}\text { Area } \\
\left(\mathrm{km}^{2}\right)\end{array}$} & \multirow{2}{*}{$\begin{array}{l}\text { Pop. } \\
(000)\end{array}$} & \multicolumn{3}{|c|}{ Age distribution \% } & \multirow{2}{*}{$\begin{array}{c}\text { Median } \\
\text { Age }\end{array}$} & \multirow{2}{*}{$\begin{array}{l}\text { Pop. } \\
\text { Growth }\end{array}$} & \multirow{2}{*}{$\begin{array}{c}\text { Pop. } \\
\text { Density }\end{array}$} & \multirow[b]{2}{*}{$C B R$} & \multirow[b]{2}{*}{$C D R$} & \multirow[b]{2}{*}{$N M R$} & \multirow[b]{2}{*}{$I M R$} & \multirow[b]{2}{*}{$T F R$} & \multirow[b]{2}{*}{$L E$} & \multirow{2}{*}{$\begin{array}{c}\text { LIT } \\
\%\end{array}$} & \multirow{2}{*}{$\begin{array}{c}\text { GDP/ } \\
\text { Pop. } \\
\text { (U.S.S) }\end{array}$} & \multirow{2}{*}{ Agr. } & \multirow{2}{*}{$\begin{array}{c}\% \\
G D P \\
\text { Ind. }\end{array}$} & \multirow[b]{2}{*}{ Ser. } & \multirow[b]{2}{*}{ LFPR } & \multirow{2}{*}{$\begin{array}{c}\% \\
\text { UN }\end{array}$} & \multirow{2}{*}{$\begin{array}{l}\text { Elect. } \\
\text { Millions }\end{array}$} & \multirow{2}{*}{$\begin{array}{c}\# \\
\text { Phones } \\
(000)\end{array}$} & \multirow{2}{*}{$\begin{array}{l}\text { Spendl } \\
\text { Pop. } \\
\text { (US S) }\end{array}$} & \multirow{2}{*}{$\begin{array}{c}\text { Visitors/ } \\
\text { Pop. } \\
\text { (2) }\end{array}$} & \multirow{2}{*}{$\begin{array}{c}\text { Status } \\
(4)\end{array}$} \\
\hline & & & $(0-14)$ & $(15-64)$ & $\overline{(65+)}$ & & & & & & & & & & & & & & & & & & & & & \\
\hline Mauritius & 1850 & 1200.0 & 24 & 69 & 7 & 30.5 & 0.84 & 649 & 15.6 & 6.8 & -0.41 & 15.0 & 1.9 & 72.4 & 85.6 & 13300 & 6.1 & 29.9 & 64.0 & 48 & 10.5 & 1800.0 & 290.2 & 788 & 0.6 & 1 \\
\hline Micronesia & 702 & 108.1 & 37 & 60 & 3 & 18.9 & -0.08 & 154 & 25.1 & 4.9 & -21.01 & 30.2 & 3.3 & 69.8 & 89.0 & 2000 & 50.0 & 4.0 & 46.0 & $35(1)$ & 16.0 & 178.6 & 93.4 & 157 & 0.2 & 1 \\
\hline Nauru & 21 & 13.0 & 38 & 61 & 2 & 20.2 & 1.83 & 619 & 25.1 & 6.8 & 0.00 & 10.0 & 3.2 & 62.7 & $87(1)$ & 5000 & - & - & - & - & 90.0 & 21.4 & 146.2 & - & - & 1 \\
\hline Palaul & 458 & 20.3 & 26 & 69 & 5 & 31.4 & 1.39 & 44 & 18.4 & 6.9 & 2.36 & 14.8 & 2.5 & 70.1 & 92.0 & 9000 & - & - & - & 48 & 2.3 & - & 330.0 & 3350 & 3.4 & 1 \\
\hline St Kitts & 269 & 38.9 & 28 & 64 & 8 & 27.6 & 0.38 & 145 & 18.1 & 8.5 & -5.90 & 14.5 & 2.3 & 72.2 & 97.0 & 8800 & 3.5 & 25.8 & 70.7 & 47 & 4.5 & 103.9 & 604.1 & 1568 & 2.4 & 1 \\
\hline St Lucia & 610 & 166.3 & 30 & 65 & 5 & 24.8 & 1.28 & 273 & 20.1 & 5.1 & -2.19 & 13.5 & 2.2 & 73.6 & 90.1 & 5400 & 7.0 & 20.0 & 73.0 & 26 & 20.0 & 261.4 & 187,0 & 1696 & 2.0 & 1 \\
\hline St Vincent & 340 & 117.5 & 27 & 66 & 7 & 26.4 & 0.27 & 346 & 16.3 & 6.0 & -7.61 & 14.8 & 1.9 & 71.8 & 96.0 & 2900 & 10.0 & 26.0 & 64.0 & 57 & 15.0 & 88.4 & 232.3 & 723 & 0.9 & 1 \\
\hline Samoa & 2850 & 177.3 & 27 & 66 & 6 & 24.6 & -0.23 & 62 & 15.9 & 6.5 & -11.73 & 27.7 & 3.0 & 70.7 & 99.7 & 5600 & 14.0 & 23.0 & 63.0 & 51 & - & 107.9 & 66.6 & 299 & 0.5 & 1 \\
\hline Sao Tome & 1001 & 187.4 & 48 & 49 & 4 & 16.1 & 3.16 & 187 & 40.8 & 6.7 & -2.51 & 43.1 & 5.7 & 67.0 & 79.3 & 1200 & 16.7 & 14.8 & 68.4 & 23 & - & 13.9 & 37.4 & 53 & 0.1 & 1 \\
\hline Seychelles & 455 & 81.2 & 26 & 67 & 6 & 27.7 & 0.38 & 178 & 16.2 & 6.3 & -5.54 & 15.5 & 1.8 & 71.8 & 91.9 & 7800 & 3.2 & 30.4 & 66.4 & 38 & - & 224.4 & 267,2 & 164 & 1.5 & 1 \\
\hline Solomons & 27450 & 538.0 & 42 & 55 & 3 & 18.6 & 2.68 & 20 & 30.7 & 4.0 & 0.00 & 21.3 & 4.0 & 72.7 & $90(1)$ & 1700 & 42.0 & 11.0 & 47.0 & 30 & - & 51.2 & 12.3 & 12 & 0.0 & 1 \\
\hline Tonga & 718 & 112.4 & 36 & 60 & 4 & 20.5 & 1.98 & 157 & 25.2 & 5.4 & 0.00 & 12.6 & 3.0 & 69.5 & 98.9 & 2300 & 23.0 & 13.0 & 64.0 & 30 & 13.3 & 31.6 & 99.6 & 133 & 0.4 & 1 \\
\hline Trinidad & 5130 & 1100.0 & 21 & 71 & 8 & 31.0 & -0.74 & 214 & 12.8 & 9.4 & -10.87 & 24.3 & 1.8 & 66.7 & 98.6 & 12700 & 0.7 & 57.0 & 42.3 & 56 & 8.0 & 5700.0 & 295.5 & 409 & 0.4 & 1 \\
\hline Tuvalu & 26 & 11.6 & 31 & 64 & 5 & 24.5 & 1.47 & 446 & 21.9 & 7.2 & 0.00 & 20.0 & 3.0 & 68.0 & $88(1)$ & 1100 & - & - & - & 60 & - & - & 60.3 & 172 & 0.2 & 1 \\
\hline Vanuatu & 14760 & 205.8 & 33 & 63 & 4 & 22.6 & 1.52 & 14 & 23.1 & 7.9 & 0.00 & 55.2 & 2.8 & 62.5 & 74.0 & 2900 & 26.0 & 12.0 & 62.0 & $40(1)$ & ـ & 38.1 & 31.6 & 345 & 0.3 & 1 \\
\hline
\end{tabular}

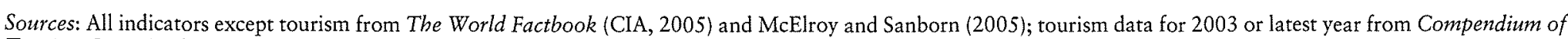
Tourism Statistics 2005 (WTO, 2005).

Notes

1 Authors' estimate based on level of development and regional norms.

2 Calculated as number of stay-over tourists plus (one-day visitors $\times 0.14$ ) divided by the resident population.

3 The two tourism indicators for Netherland Antilles exclude Saba and St Eustatius.

4 ' 1 ' denotes sovereign political status and ' 0 ' denotes affiliation. 